\title{
Entrepreneur behavior of young educated farmers in the covid -19 pandemic
}

\author{
Siti Nurlaela* and Sujono \\ Sustainable Agricultural Extension Study Program, Agricultural Development Polytechnic \\ Yogyakarta-Magelang, Yogyakarta, Indonesia
}

\begin{abstract}
The Covid 19 pandemic has an impact on young farmer entrepreneurs. Business income has dropped drastically, and the distribution process is experiencing difficulties. Entrepreneurial behaviour is needed so that young farmers can cope with the impact of Covid 19. This research seeks to analyze the entrepreneurial behaviour of young farmers during the Covid 19 period. The sample is all educated young farmers who participated in the PWMP program (Agricultural Young Entrepreneur Development) - using a google form from 90 participants who were willing to fill out 71 young farmers. The research variables were: the ability to survive in entrepreneurship (X1), the use of new media for entrepreneurship (X2), and business success during the Covid period (X3). Percentage, mean score, and regression analysis at $p \leq 0.05$ were employed to analyze the data. There was a significant effect $(p \leq 0.05)$ between $\mathrm{X} 1$ and $\mathrm{X} 2$ on $\mathrm{X} 3$ of $28.1 \%$. The ability to survive in entrepreneurship (X1) has a significant effect, while new media for entrepreneurship (X2) is insignificant. The government is expected to protect young farmers' businesses by providing additional capital, marketing and business assistance in collaboration with successful entrepreneurs.
\end{abstract}

\section{Introduction}

The COVID-19 pandemic has had a significant impact on agricultural businesses. It is difficult for entrepreneurs to carry out the production and marketing processes, such as; production facilities, find labour, and restrict working time. Meanwhile, related to marketing, farmers have experienced difficulties selling agricultural products due to restrictions on mobility between regions and decreased community purchasing power. On the other hand, farmers will experience losses because of unsold agricultural products by the market [1-4].

Indonesia is an agricultural country, with the majority of the population being farmers. They continue to survive in their farming even though many have suffered losses. Meanwhile, the government also tried to suppress the spread of the Covid 19 virus by implementing social restriction regulations. Everyone should stay at home and reduce mobility outside the home. The various impacts of this social restriction policy include: low

\footnotetext{
Corresponding author: nurlaela77yk@gmail.com
} 
agricultural production, increased unemployment and decreased income of farmers and small business actors [5].

Young farmers who have just started farming businesses are feeling the impact of this pandemic. They have to do various ways in order to survive with their agricultural business. Some have given up and stopped production because they continued to suffer losses. Middendorf et al. [6] argue that farmers have low perceptions of their success in dealing with crises. In this uncertain condition, many young farmers never give up. Some young educated farmers continue to try to maintain their business despite the difficult conditions. Entrepreneurship in the suit period requires creative and innovative abilities, especially in agriculture, as researched by [7]. The young farmer must be energetic, creative and innovative, especially in the agricultural business during the pandemic. The characteristics of agricultural entrepreneurship include perishable agricultural products, fluctuating prices, and climate change [8].

Furthermore, the young farmers are $\mathrm{Z}$ generation, who are accustomed to using new media. FAO states that new media can help marketing and make it easier for farmers to communicate and find information [9]. Young entrepreneurs use new media for image building, strengthening relationships, and networking among business entrepreneurs and customers $[10,11]$. Entrepreneurial behaviour during the Covid 19 pandemic is interpreted by the efforts of young farmers to stay in business by looking for opportunities, taking advantage of opportunities, increasing creativity and innovation [7]. In addition, young farmers are also $\mathrm{Z}$ generation who are very familiar with new media, including entrepreneurship. This study will analyze the efforts of educated young farmers in entrepreneurship amid a pandemic. The findings of this study are expected to provide an overview of the entrepreneurial behaviour of young farmers, which consists of creative and innovative abilities amid a crisis and the use of new media to support businesses during a pandemic on the success of young farmers' businesses.

\section{Methodology}

This research used a quantitative descriptive approach-research locations in Indonesia. Meanwhile, the research subjects were young entrepreneurs in the farmer regeneration program of the Ministry of Agriculture who received entrepreneurial capital in 2019. The research was conducted from January to April 2021. All PWMP participants became research respondents. Of the 90 participants, 71 young farmers filled out the questionnaire via a google form - the independent variables are entrepreneur behaviour and utilizing new media measured by a Likert scale. The dependent variable, namely business success, is also measured by a Likert scale. The variables are using a 5 -score rating scale that includes; (1) Very Unsuitable, (2) Unsuitable, (3) Doubtful, (4) Suitable, (5) Very Suitable. Age is measured by years. Percentages and average scores are used to analyze the personal characteristics of young educated farmers. The influence of entrepreneurial behaviour and utilizing new media on business success is measured by multiple regression analysiscorrelation at $\mathrm{p} \leq 0.05$.

\section{Results and Discussion}

\subsection{Characteristics of Young Educated Farmers}

Based on Table 1, the male is more than women, but only a little. In the modern agricultural concept, the roles of women and men are balanced. Physical work, which was originally only done by men, can be done by women with the help of technology, as researched by 
[12]. The majority of educated young farmers are undergraduate graduates (91.5\%). Young farmers with higher education graduates have better creativity than senior farmers. Young farmers can manage their farming to become modern and business-oriented, as researched by [7]. The majority of educated young farmers are farmers' children (43.6\%). According to Hoffmann et al. [13], parents become role models for their children. In addition, the family also has a vital role in helping the success of the business, as the findings of Rachmania et al. [14].

Table 1. Characteristics of Young Educated Farmers

\begin{tabular}{|l|c|c|}
\hline \multicolumn{1}{|c|}{ Variable } & $\begin{array}{c}\text { Number of } \\
\text { farmers }\end{array}$ & $\begin{array}{c}\text { Percentage } \\
\text { (n=71) }\end{array}$ \\
\hline Sex & & \\
\hline Man & 40 & 57.7 \\
\hline Woman & 31 & 42.3 \\
\hline Age (year) & 62 & 87.3 \\
\hline $20-25$ & 9 & 12.7 \\
\hline$>25-35$ & & \\
\hline Education & 6 & 8.5 \\
\hline Senior High School & 65 & 91.5 \\
\hline University (Higher Education) & & \\
\hline Residence & 9 & 12.7 \\
\hline Yogyakarta & 43 & 60.5 \\
\hline Central Java & 2 & 2.8 \\
\hline East Java & 2 & 2.8 \\
\hline West Java & 2 & 2.8 \\
\hline Jakarta & 12 & 17 \\
\hline Kalimantan & 1 & 1.4 \\
\hline Maluku & & \\
\hline Type of business & 36 & 50.7 \\
\hline Cultivation & 5 & 7.1 \\
\hline Cultivation and Marketing & 12 & 16.9 \\
\hline Marketing & 12 & 16.9 \\
\hline Animal Husbandry & 6 & 8.4 \\
\hline Processing & \multicolumn{2}{|c|}{} \\
\hline
\end{tabular}

Furthermore, the majority of young farmers chose cultivation entrepreneurs $(50.7 \%)$. Exceptionally few choose agricultural processing and marketing businesses. Farmers who have just started a business usually prefer cultivation because they continue their existing agricultural business. Also, they are inexperienced and do not have a relationship in the marketing and processing business.

\subsection{Entrepreneurial Behaviour of Educated Young Farmers during The Covid Pandemic 19}

The entrepreneurial behaviour of young farmers is defined as the ability to survive in entrepreneurship with creativity and innovation. Young farmers have higher creativity than older farmers.

Based on Table 2, the mean ability to survive in entrepreneurship is 3.5 or hesitant. The uncertainty of entrepreneurship in this pandemic encourages youth to make various efforts even though they have not been successful. All businesses affected by the pandemic include agricultural businesses [15]. The highest effort was made by finding information on agricultural products that were of interest during the Covid period (4.1). One of the 
successes of entrepreneurship is finding as much information as possible about the most appropriate and salable products in this Covid era. This information is used to prepare more measurable business steps. Accuracy in determining the type of business development will ensure the success of entrepreneurs [16]. Young farmers are expected to have the ability to continue to learn and analyze the conditions for the success of their business [17].

Table 2. Table of entrepreneur behaviour of young farmers during the Covid 19 Pandemic

\begin{tabular}{|l|c|}
\hline \multicolumn{1}{|c|}{ Statement } & Score \\
\hline $\begin{array}{l}\text { Looking for information on agricultural products that are of interest during the } \\
\text { Covid period }\end{array}$ & 4.1 \\
\hline $\begin{array}{l}\text { Looking for new opportunities by creating more profitable products in the } \\
\text { Covid era }\end{array}$ & 4.0 \\
\hline Mitigate the impact of covid on business & 3.3 \\
\hline Looking for the right market in the Covid era & 4.0 \\
\hline Fulfilling market needs during the covid period & 3.2 \\
\hline Selling on the modern market during covid & 3.1 \\
\hline Doing good management during the covid period & 3.6 \\
\hline Adding business networks during the covid period & 3.5 \\
\hline Increase business capacity during the Covid period & 3.2 \\
\hline Making several product/business variants during the covid period & 3.3 \\
\hline Mean & 3.5 \\
\hline
\end{tabular}

Young farmers are hesitant to expand their business during the Covid period, significantly penetrating modern markets such as supermarkets and modern shops. Young farmers do not have a vast network. Their business capacity and business experience are still very minimal. Young farmers need to continue collaborating and developing business networks to develop, as research by Björklund et al. [18].

\subsection{Utilization of New Media in Entrepreneurship during a Pandemic}

Young farmers are classified as a native generation towards advances in information technology. This ability is very much needed in the new media era, especially during a pandemic. Table 3 reveals the use of new media for young farmers to do business during a pandemic

Table 3 Utilization of New Media in Entrepreneurship during the Pandemic Period

\begin{tabular}{|l|c|}
\hline Statemen & Score \\
\hline $\begin{array}{l}\text { Using new media to find information on business opportunities during the } \\
\text { Covid period. }\end{array}$ & 3.8 \\
\hline Using new media to find information on competitors' progress & 3.8 \\
\hline Using new media to find pricing information & 3.9 \\
\hline Cooperate with the marketplace for delivery & 3.0 \\
\hline Cooperating with marketplaces to sell products & 2.9 \\
\hline Using paid social media to market products & 2.6 \\
\hline Using social media to market products (Wa, Fb, Insta, etc.) & 4.1 \\
\hline Communicating using social media & 4.1 \\
\hline Creating an attractive marketing design/media content & 3.5 \\
\hline Improve digital business capabilities & 3.7 \\
\hline Issue costs for more vigorous promotion & 3.4 \\
\hline Increase online-based customers & 3.6 \\
\hline Increase promotion to increase buyers on line & 3.4 \\
\hline Utilizing information from the internet for business progress & 3.7 \\
\hline Trying to select and sort information that is important for business progress & 3.7 \\
\hline Mean & $\mathbf{3 . 3}$ \\
\hline
\end{tabular}


Based on Table 3, young farmers still hesitate to use new media for entrepreneurship during a pandemic (3.3). This doubt is because young farmers have not received specific training regarding the use of new media for business. They only use new media for their daily activities. For example, to communicate, seek information and build relationships (Nurlaela et al., 2020). This result is confirmed by the high achievements in using social media to market products (4.1) and communicate (4.1). Meanwhile, young farmers do not feel the need to spend money to market their products. They still use conventional methods such as using Wa group or updating status Wa or on Facebook.

\subsection{The Success of Young Farmers' Businesses during a Pandemic}

This young farmer, who is an alumnus of agricultural college graduates, receive capital in 2019. The amount of profit does not measure business success in the PWMP program because of the short business time. This study measures the business success of a continuously carried out process by young farmers to stay afloat in the agricultural business. The success of agricultural entrepreneurs in the PWMP program is measured by group cohesiveness, ability to build business networks, entrepreneurial skills and willingness to develop a business. Entrepreneurial learning is a process to prepare agricultural entrepreneurs to be measured by attitudes and potential abilities as entrepreneurs [19]. Meanwhile, [20] assessed that this program was successful because it could positively influence entrepreneurship.

Based on Table 4, these young farmers implementing entrepreneurship are in progress and continue to build a sound management system. However, due to the pandemic's impact, some young farmers have stopped their business and feel unable to continue their business. Table 4 shows the level of entrepreneurial success of young farmers. The success of the business is still doubtful (3.9).

Table 4 The Success of Young Farmers during the Covid-19 Pandemic

\begin{tabular}{|l|c|}
\hline \multicolumn{1}{|c|}{ Statement } & Score \\
\hline Group cohesiveness & 4.0 \\
\hline Continues to increase the business network & 3.3 \\
\hline Gaining new knowledge and experience in business & 4.6 \\
\hline Confident to be a successful young farmer & 4.0 \\
\hline Willingness to develop business & 4.1 \\
\hline Mean & $\mathbf{3 . 9}$ \\
\hline
\end{tabular}

Young farmers have new knowledge and experience in business (4.6). This value indicates the success of the PWMP program qualitatively. One of the goals of entrepreneurship education is to provide experience and interest in prospective entrepreneurs expected to become successful entrepreneurs. This approach is also widely used in farmer regeneration programs in Europe [21,22].

\subsection{The Influence of Entrepreneurial Behaviour on The Business Success of Young Farmers during The Pandemic}

Table 5 shows the influence of entrepreneurial behaviour and the use of new media on business success ( $\mathrm{R}$ Square 28.1\%). This effect is significant because the F-calculated value $(13,305)$ is higher than the F-table (3.13) at a significance level of $p \leq 0.01$. The model of the influence of each variable in a row, that is, entrepreneurial behaviour, has a positive effect. Meanwhile, the use of new media does not affect business success. The equation can be stated as follows: $\mathrm{Y}=2.376+0.344 \mathrm{X} 1$. The regression equation can be interpreted that 
each increase in the entrepreneurial behaviour of 1 (one) point can increase the business's success by 0.344 .

Table 5. The influence of entrepreneurial behaviour and the use of new media on business success

\begin{tabular}{|l|l|l|l|}
\hline Variable & Regression Coeff & T-Calc & Sign \\
\hline Entrepreneur behaviour (X1) & 0.344 & 2.424 & $0.018^{* *}$ \\
\hline The Role of new media (X2) & 0.231 & 1.628 & 0.108 \\
\hline Constant & 2,376 & & \\
\cline { 1 - 2 } R-Square & 0.281 & \\
\cline { 1 - 2 } Adjusted R Square & 0.260 & \\
\cline { 1 - 2 } F-Calc & 13.305 & \\
Note: * Significant on the level of $0.05, * *$ Significant at 0.01
\end{tabular}

Entrepreneurial behaviour and the use of new media together can increase business, but only partially entrepreneurial behaviour significantly affects business success. Various findings have explained that the business's success is influenced by the spirit of never giving up, being creative, innovative, and building networks. The success of young farmers is determined by the motivation and use of ICT [23]. In this study, entrepreneurial success is influenced by entrepreneurial behaviour and the use of new media for business.

Entrepreneurial behaviour is critical in increasing business success. Farmers who have good entrepreneurial skills will manage businesses, such as; initiative ability, ability to take risks, creativity or innovation [24]. The importance of entrepreneurial behaviour is also found in farmers in Asia and Africa [25].

Meanwhile, the use of new media partially does not affect the business's success because the skills of young farmers in utilizing new media for business are still lacking. Most of the young farmers still use conventional methods to market their business. They sell their crops to traders/intermediaries; only about 30\% have used new media to support marketing. Young farmers should maximize the new media for farming, but not for these newcomer farmers. They have just learned entrepreneurship, so they lack business experience. The term young farmer is not appropriate for students who have just graduated from this agricultural college. They need time to learn to be tough farmers, including strategies to utilize new media such as [26] research.

\section{Conclusions and Recommendations}

Young farmers are generally more interested in on-farm businesses. The success of young farmers' businesses is influenced by entrepreneurial behaviour, which is defined as the ability to survive in entrepreneurship with creativity and innovation. The use of new media does not affect the business's success because it lacks the skills to use new media for business. In addition, they are still relatively new to entrepreneurship. It is hoped that the government can continue to encourage young farmers to improve entrepreneurial behaviour by providing assistance, increasing capital, helping with marketing and getting closer to successful entrepreneurs through the partnership program.

\section{References:}

1. V. Iese, M. Wairiu, G. M. Hickey, D. Ugalde, D. Hinge, J. Walenenea, T. Tabe, M. Keremama, C. Teva, O. Navunicagi, J. Fesaitu, R. Tigona, D. Krishna, H. Sachan, N. Unwin, C. Guell, E. Haynes, F. Veisa, L. Vaike, Z. Bird, M. Ha, N. Roko, S. Patolo, A. Rose, S. Kiran, P. Tikai, J. Tuiloma, S. Halavatau, J. Francis, and A. Christopher, 
Agric. Syst. 190, 103099 (2021).

2. P. Kumar, S. S. Singh, A. K. Pandey, R. Kumar, P. Kumar, M. Kumar, S. Kumar, U. Sah, R. Nandan, S. Kumar, P. Agrawal, A. Kushwaha, M. Rani, J. Kumar, and M. Drews, Agric. Syst. 187, 103027 (2021).

3. A. U. Ofuoku and E. A. Ikpoza, 12, 49 (2021).

4. R. Siche, Sci. Agropecu. 11, (2020).

5. Z. Rozaki, Rev. Agric. Sci. 8, 243 (2020).

6. B. J. Middendorf, A. Faye, G. Middendorf, Z. P. Stewart, P. K. Jha, and P. V. V. Prasad, Agric. Syst. 190, 103108 (2021).

7. P. Milone and F. Ventura, J. Rural Stud. 65, (2019).

8. S. Sohoo, in Proc. Int. Conf. Comput. Sci. Inf. Technol. ICCSIT 2008 (2008).

9. FAO, Information and Communication Technology ( ICT ) in Agriculture: A Report to the G20 Agricultural Deputies (2017).

10. R. Kahar, F. Yamimi, G. Bunari, and H. Habil, Procedia - Soc. Behav. Sci. 66, 564 (2012).

11. G. John, P. D. Igwe, and S. R. P. D. Abiye, Eur. J. Bus. Soc. Sci. 3, 103 (2014).

12. A. Joseph Fernando, Mol. Plant 13, 1345 (2020).

13. A. Hoffmann, M. Junge, and N. Malchow-Møller, Small Bus. Econ. 44, 79 (2015).

14. I. N. Rachmania, M. Rakhmaniar, and S. Setyaningsih, Procedia Econ. Financ. 4, 234 (2012).

15. J. Kithiia, I. Wanyonyi, J. Maina, T. Jefwa, and M. Gamoyo, Data Br. 33, 106317 (2020).

16. J. Chavez, Helsinki Metrop. Univ. Appl. Scineces May, 40 (2016).

17. F. Karakas, A. Manisaligil, and E. Sarigollu, Int. J. Manag. Educ. 13, 237 (2015).

18. J. Santrock, Jakarta: Erlangga (2002).

19. N. Saad and Z. Z. Ariffin, Int. J. Econ. Financ. Issues 6, 31 (2016).

20. D. T. Yunandar, S. S. Hariadi, and A. B. Raya, J. Agric. Ext. 23, 147 (2019).

21. D. May, S. Arancibia, K. Behrendt, and J. Adams, Land Use Policy 82, 317 (2019).

22. K. Davis, E. Nkonya, E. Kato, D. A. Mekonnen, M. Odendo, R. Miiro, and J. Nkuba, World Dev. 40, 402 (2012).

23. O. Anwarudin, S. Sumardjo, A. Satria, and A. Fatchiya, Int. J. Innov. Technol. Explor. Eng. 9, 1008 (2019).

24. V. Barba-sánchez, C. Atienza-sahuquillo, V. B. Sánchez, and C. A. Sahuquillo, 2523, (2012).

25. M. Benjamin, Asian J. Agric. Extension, Econ. Sociol. 22, 1 (2018).

26. L. Zagata and L. A. Sutherland, J. Rural Stud. 38, 39 (2015). 